\title{
Sources and Acknowledgments
}

A large part of this volume is drawn from a personal journal that I maintained every day of my ten years as chairman of the Atomic Energy Commission. The journal, having been written often in haste at the end of a busy day, was not always couched in optimum phraseology. In various places, therefore, I have allowed myself the privilege of altering a word or phrase. As John Kenneth Galbraith noted in justifying similar changes in his fascinating Ambassador's Journal, "No historical merit attaches to bad English."

A number of individuals who were engaged in or privy to the events leading to the test ban have been most generous in sharing their recollections and observations with me. Theodore Sorensen, who as special counsel and principal speechwriter was among the closest to John F. Kennedy, contributed some key insights. Norman Cousins, Jerome Wiesner, Franklin Long, Herbert York, and Warren Heckrotte supplied rich detail about important episodes, in some of which they played leading roles. I am most especially indebted to W. Averell Harriman, who not only described the background and details of his climactic negotiations in Moscow in several extended conversations but also permitted access to his personal files.

The staff of the John Fitzgerald Kennedy Memorial Library provided liberal access to the library's rich documentary resources, notably including the remarkable collection of oral history interviews. I am also indebted to the Kennedy Library for a number of the photographs used to illustrate the text.

To make the story as coherent and complete as possible I have made liberal use of government documents-in particular the excellent reports issued on a current basis by the Arms Control and Disarmament Agency-and of books and articles, both scholarly and journalistic. These are cited if they are quoted or if the item involved seems relatively unfamiliar. I did not think it necessary to show sources for better known facts or events.

The completion of this book owes much to a number of people who provided important assistance along the way. Valuable suggestions on substance and style were offered by those who read early drafts: Paul Seabury, Lillian O. Lukaczer, Francis Duncan, Walter G. Leight, Milton Turen, Ellen Loeb, and Jeanne L. Loeb. Lin Lorenz coordinated the preparation of the manuscript, nursing it through its several vintages with critical intelligence and care, unflagging indus- 
try, and unfailing good humor. Further administrative support was contributed by Patricia Johnson.

My daughter, Lynne Cobb, provided valuable criticism of an early draft.

Finally, I am indebted, as always, to my wife, Helen, for her encouragement, support, and wise counsel.

Berkeley, California 1981

G. T.S 